\title{
Survey and Analysis of Employment Status of Graduates in Harbin Finance University During the Past Three Years
}

\author{
Xuejie Bai \\ Management Department \\ Harbin Finance University \\ Harbin, China
}

\begin{abstract}
Graduate employment is an important social problem and graduate employment quality is relevant to the survival and development of universities. Employment status is a key parameter to the assessment of students' quality of higher education. Harbin Finance University is a newly-built university including underguaduates and junior colleges.The employment data of graduates of Harbin Finance University over the past three years were analyzed such as initial employment rate, career choice, industry flow of employment, distribution comparisons and so on. After analyzing the status of the graduate employment, exploring strategies of improving the quality of university students' employment, we hope to provide valuable suggestions and improve the career guidance service and the quality of talents training of Harbin Finance University.
\end{abstract}

Keywords-Distribution of employment; graduates; employment survey; entrepreneurship

\section{INTRODUCTION}

During the years between 2000 and 2015 there're 403 newly-built local universities, nearly a half of the colleges and universities all over China.The establishment of local universities means the regional development of higher education in China. It's valuable for the colleges and universities to construct a mode of aiming to job-hunting and developing ability according to regular patterns of cultivating applied talents and combining the features of different majors. With the development of the socialist market economy many universities have set up economic and management majors. But some problems exist in the schools and these affect a lot.In the article we take Harbin Finance University as an example to investigate and analyze that how degree hierarchy, speciality structure, regional economy development,industry and nature of unit influence university graduate employment rate and quality in the last three years.

Harbin Finance University is located in Northeast of China. It was founded in 1950 and is the first Chinese Finance College. In April 2010, approval of the Ministry of Education, Harbin Finance College was renamed as Harbin Finance University, an application-oriented university. The construction area of Harbin Finance University is around 642,900 square meters. There are 752 faculties and nearly 10,000 students from thirty provinces all over China in this university. The university has ten departments, 16 junior college courses and 22 undergraduate majors covering literature, economics, law, engineering, management five disciplines. For over sixty years this school has graduated close to 50,000 students. The majority of the graduates distributes in financial domain, such as bank, insurance, negotiable securities, stock, trust, and become the backbone of the business unit.The deadline of all data about agreement in the article is August 31st the next year.

\section{TOTAL EMPLOYMENT STATUS OF GRADUATES DURING THE PAST THREE YEARS}

\section{A. Size and Structure}

We can see the numbers of the students of Harbin Finance University during the past three years from "Table I'. They are 3,847 in 2014, 3757 in 2015 and 2,696 in 2016. The university has decreased the number of recruiting students and junior colleges step by step, but the number of recruiting undergraduate is increasing step by step. Girls now make up nearly 70 percent of all the students.

TABLE I. BASIC SitUATION

\begin{tabular}{c|c|l|l|l|l|l|l|l|r}
\hline \multirow{2}{*}{ Time } & \multirow{2}{*}{ Total } & \multicolumn{2}{|c|}{ Undergraduate } & \multicolumn{2}{c|}{ Junior College } & \multicolumn{2}{c|}{ Male } & \multicolumn{2}{c}{ Female } \\
\cline { 3 - 10 } & & Quantity & Percentage & Quantity & Percentage & Quantity & Percentage & Quantity & Percentage \\
\hline $\mathbf{2 0 1 4}$ & 3847 & 2084 & 54.17 & 1763 & 45.83 & 1120 & 29.11 & 2727 & 70.89 \\
\hline $\mathbf{2 0 1 5}$ & 3757 & 2041 & 54.33 & 1716 & 45.67 & 1148 & 30.56 & 2609 & 69.44 \\
\hline $\mathbf{2 0 1 6}$ & 2696 & 1958 & 72.63 & 738 & 27.37 & 763 & 28.3 & 1933 & 71.7 \\
\hline
\end{tabular}




\section{B. Initial Employment Rate}

For years Harbin Finance College in the quality of personnel training, graduate employment and other aspects of society have been widely recognized. With the development of the economic globalization economics and management undergraduates are becoming more easily to find jobs now. The initial employment rate is all above $80 \%$ and is growing slowly from 2014 to 2016. There is no significant difference in initial employment rate between undergraduate and junior college. "Table II"

TABLE II. COMPARISON OF INITIAL EMPLOYMENT RATE

\begin{tabular}{l|l|l|l}
\hline & $\begin{array}{c}\mid c \\
\text { Initial } \\
\text { Employment Rate }\end{array}$ & Undergraduate & $\begin{array}{c}\text { Junior } \\
\text { College }\end{array}$ \\
\hline $\mathbf{2 0 1 4}$ & $84.33 \%$ & $81.43 \%$ & $87.75 \%$ \\
\hline $\mathbf{2 0 1 5}$ & $88.34 \%$ & $87.95 \%$ & $88.81 \%$ \\
\hline $\mathbf{2 0 1 6}$ & $89.43 \%$ & $89.38 \%$ & $89.57 \%$ \\
\hline
\end{tabular}

C. Choices after Graduation

The employment choices go into six types: employment contract, flexible employment, higher education, unemployment contracts and other employments. From 2014 to 2016 there is no significant difference in employment contract rate for junior college students. "Table III"

More and more students are admitted into higher education. Facing with the increasingly stern situation of employment, more and more undergraduates choose the way of trying for master programs to find the development opportunities. Very few undergraduates go abroad for education.In this newly-built university the fractional line for junior college students is close to that of the undergraduates in Heilongjiang Province and this means they have advantage and greater possibility of being admitting by higher education comparing with the other junior college students in Heilongjiang Province. In addition there is much more educational experience for junior college students and pre-entrance training organized by the school also play a big role. Newly-built universities are weak in education philosophy, study atmosphere, specialty foundation, students'quality, teaching management and teachers' level. They're not good for the students in the school to be admitted to get postgraduate degree comparing with other undergraduate in other universities with a long history.

TABLE III. ChOICES AFter GRADUATION (IN\%)

\begin{tabular}{c|l|l|l|l|l|l}
\hline \multirow{2}{*}{$\begin{array}{c}\text { Employment } \\
\text { Category }\end{array}$} & \multicolumn{2}{|c|}{$\mathbf{2 0 1 4}$} & \multicolumn{2}{c|}{$\mathbf{2 0 1 5}$} & \multicolumn{2}{c}{$\mathbf{2 0 1 6}$} \\
\cline { 2 - 6 } & $\begin{array}{c}\text { Under } \\
\text { graduate }\end{array}$ & $\begin{array}{c}\text { Junior } \\
\text { College }\end{array}$ & $\begin{array}{c}\text { Under } \\
\text { graduate }\end{array}$ & $\begin{array}{c}\text { Junior } \\
\text { College }\end{array}$ & $\begin{array}{c}\text { Under } \\
\text { graduate }\end{array}$ & $\begin{array}{c}\text { Junior } \\
\text { College }\end{array}$ \\
\hline Employment Contract & 63.34 & 53.6 & 44.34 & 56.76 & 56.69 & 56.78 \\
\hline Flexible Employment & 16.22 & 14.35 & 40.08 & 7.11 & 28.96 & 3.66 \\
\hline Higher Education & 1.54 & 19.80 & 2.84 & 24.83 & 2.71 & 28.86 \\
\hline Going abroad & 0.33 & 0 & 0.69 & 0.06 & 0.41 & 0 \\
\hline Unemployment Contract & 18.57 & 12.25 & 12.05 & 11.19 & 10.62 & 10.43 \\
\hline Other Employments & 0 & 0 & 0 & 0.06 & 0.61 & 0.27 \\
\hline Total & 100 & 100 & 100 & 100 & 100 & 100 \\
\hline
\end{tabular}

\section{DistRIBUTION OF EMPLOYMENT DURING THE PAST} THREE YEARS

\section{A. Industry Flow of Employment}

From "Table IV" we can know industry flow of employment in the university during the past three years.Analyzing the graduate occupation fields of finance, we think multiple education patterns must be adopted to meet the talents need serving for local economy development.

The main industry categories are financial industry, information software industry, Wholesale and retail industry, manufacturing, industry, leasing and business service and others. Harbin Finance University as a financial college servicing to local economic development have deepened the reform of practice teaching and cultivated many applied talents for the society for more than sixty years. Graduates are interested in financial industry not only because the university's history but also they may get good salary and comfortable working condition in commercial fields. The percentage of undergraduate in financial industry is from $45.53 \%$ to $41.4 \%$, but that of junior college has the trend of decrease from $33.12 \%$ to $15.75 \%$ during the past three years. The competition between different colleges in financial industry is very strong. With the internet's entry to commercializing developmental stage new industries and millions of new jobs are created. The severe competition in the job market eventually convert some students to the idea that they just want to work in financial industry.

TABLE IV. INDUSTRY FLOW OF EMPLOYMENT (IN \%)

\begin{tabular}{|c|c|c|c|c|c|c|}
\hline \multirow[b]{2}{*}{ Industry Category } & \multicolumn{2}{|c|}{2014} & \multicolumn{2}{|c|}{2015} & \multicolumn{2}{|c|}{2016} \\
\hline & $\begin{array}{c}\text { Under } \\
\text { graduate }\end{array}$ & $\begin{array}{c}\text { Junior } \\
\text { College }\end{array}$ & $\begin{array}{c}\text { Under } \\
\text { graduate }\end{array}$ & $\begin{array}{l}\text { Junior } \\
\text { College }\end{array}$ & $\begin{array}{c}\text { Under } \\
\text { graduate }\end{array}$ & $\begin{array}{c}\text { Junior } \\
\text { College }\end{array}$ \\
\hline Financial Industry & 45.53 & 33.12 & 47.29 & 21.13 & 41.4 & 15.75 \\
\hline Wholesale and Retail Industry. & 9.77 & 8.89 & 11.93 & 19.59 & 11.36 & 21.48 \\
\hline Manufacturing Industry & 6.29 & 8.15 & 8.40 & 13.33 & 8.50 & 9.31 \\
\hline Information Software Industry & 4.32 & 4.34 & 6.85 & 5.03. & 8.59 & 8.59 \\
\hline Leasing and Business Service & 9.77 & 10.05 & 5.52 & 3.69 & 5.90 & 5.01 \\
\hline
\end{tabular}




\section{B. Destribution Comparison of Family Location and Working Place}

In the survey of employment status of graduates distribution flow include seven geographic regions in "Table V'. From the table below we can see graduates tend to find jobs and live in urbanized areas, such as South China, North China and EastChina. North East refers to Heilongjiang Province, Jilin Province and Liaoning Province.The percentage of undergraduate came from North East is $74.76 \%$ in 2014, $70.7 \%$ in 2015 and $69.67 \%$ in 2016. But percentage of undergraduates returning to North East is only $63.10 \%$ in 2014, $56.88 \%$ in 2015 and $49.55 \%$ in 2016. Most of the junior college students choose to work back to North East. Education level affects the university students' employment. Graduates from under-developed regions such as Central China and North West choose not to go back their hometown. With the practice of market economy in our country and the subsequent reform in the job allocation system, the students' sense of job-hunting has greatly changed. There is a vicious circle between the development of northeast, central and western underdeveloped areas and the employment of high-education institutions graduates. The brain drain may also undermine regional economy development plan in future.

TABLE V. DESTRIBUTION COMPARISON OF FAMILY LOCATION AND WORKING PLACE (IN \%)

\begin{tabular}{|c|l|l|l|l|l|l|l|}
\hline $\begin{array}{c}\text { Geographica } \\
\text { Regions }\end{array}$ & \multirow{2}{*}{$\begin{array}{c}\text { Comparative } \\
\text { Contents }\end{array}$} & \multicolumn{3}{|c|}{ Undergraduate } & \multicolumn{3}{c|}{ Junior College } \\
\cline { 3 - 8 } South China & Family Location & 2.3 & 2.20 & 2.30 & 1.02 & 0.81 & 0.81 \\
\cline { 2 - 8 } & Working Place & 10.23 & 9.05 & 11.2 & 10.05 & 4.14 & 2.62 \\
\hline \multirow{2}{*}{ Central China } & Family Location & 3.17 & 3.43 & 3.47 & 2.95 & 2.74 & 2.03 \\
\cline { 2 - 8 } & Working Place & 2.58 & 2.23 & 2.33 & 0.63 & 0.53 & 0.95 \\
\hline \multirow{2}{*}{ South West } & Family Location & 3.98 & 4.95 & 5.36 & 1.53 & 1.75 & 3.25 \\
\cline { 2 - 8 } & Working Place & 4.09 & 4.52 & 5.38 & 0.85 & 0.53 & 2.14 \\
\hline \multirow{2}{*}{ North West } & Family Location & 4.32 & 6.91 & 7.2 & 3.35 & 4.08 & 3.66 \\
\cline { 2 - 8 } & Working Place & 2.88 & 4.64 & 4.03 & 1.59 & 2.02 & 1.19 \\
\hline \multirow{2}{*}{ East China } & Family Location & 4.37 & 3.77 & 3.73 & 1.76 & 0.99 & 1.36 \\
\cline { 2 - 8 } & Working Place & 6.44 & 9.93 & 11.92 & 4.87 & 4.58 & 3.81 \\
\hline \multirow{2}{*}{ North East } & Family Location & 7.10 & 8.04 & 8.27 & 3.18 & 3.15 & 5.42 \\
\cline { 2 - 8 } & Working Place & 10.68 & 12.75 & 15.59 & 4.02 & 2.91 & 4.76 \\
\cline { 2 - 8 } & Family Location & 74.76 & 70.7 & 69.67 & 86.21 & 86.48 & 83.47 \\
\hline
\end{tabular}

\section{Nature of the Employment Unit}

Most of the graduates work in the five kinds of units.State-owned enterprise and private enterprise hire more than $80 \%$ students. State-owned enterprise reorganizations mainly in property rights system innovation are conducted deeply all around China and competition for jobs rises. These make more difficult for graduates to get jobs in the stateowned enterprise. The percentage of junior college students declined sharply from $46.67 \%$ in 2014 to $16.23 \%$ in 2016. The percentage of undergraduate employed by foreignfunded enterprise is $1.97 \%$ in $2014,1.33 \%$ in 2015 and $1.06 \%$ in 2016 . The percentage of undergraduates employed by foreign-funded enterprise in 2015 is less than $2 \%$, lower than the average of $22.8 \%$ in Heilongjiang Province.Many foreign employers emphasize their applicants to have certain level of English and comprehensive quality. From the "Table VI" we can see private employers are ramping up hiring and more and more graduates tend to works facing severe employment situation.Under the tendency of global economy integralization the fight for talent becomes intense day and night by foreign investment and private owned enterprise. It is the most important thing for the school to resolve the problem how to reform, improve undergraduate training model, enhance the quality of higher education further and make its students to be more competitive than students' peers.

TABLE VI. NATURE OF THE EMPLOYMENT UNIT (IN \%)

\begin{tabular}{c|c|c|c|c|c|c}
\hline \multirow{2}{*}{ Nature of Employment Unit } & \multicolumn{2}{|c|}{$\mathbf{2 0 1 4}$} & \multicolumn{2}{c|}{$\mathbf{2 0 1 5}$} & \multicolumn{2}{c}{$\mathbf{2 0 1 6}$} \\
\cline { 2 - 7 } & $\begin{array}{c}\text { Under } \\
\text { graduate }\end{array}$ & $\begin{array}{c}\text { Junior } \\
\text { College }\end{array}$ & $\begin{array}{c}\text { Under } \\
\text { graduate }\end{array}$ & $\begin{array}{c}\text { Junior } \\
\text { College }\end{array}$ & $\begin{array}{c}\text { Under } \\
\text { graduate }\end{array}$ & $\begin{array}{c}\text { Junior } \\
\text { College }\end{array}$ \\
\hline State-owned Enterprise & 59.39 & 46.67 & 48.18 & 18.56 & 43.20 & 16.23 \\
\hline Other Enterprise & 34.62 & 46.67 & 47.4 & 73.23 & 52.06 & 74.46 \\
\hline Foreign-funded enterprise & 1.97 & 0 & 1.33 & 0 & 1.06 & 0.48 \\
\hline State Organ & 1.36 & 2.33 & 1.66 & 3.38 & 0.36 & 0 \\
\hline Other Institution & 0.91 & 1.90 & 0.11 & 1.44 & 1.70 & 5.25 \\
\hline
\end{tabular}

\section{CONCLUSION}

After analyzing the employment status of graduates in Harbin Finance University during the past three years we can draw a conclusion as a newly-built local university the situation of employment is favorable and the teaching quality control system has ensured the steady promotion of qualified personnel. The survey shows some problems in instruction and management of students are to be solved gradually. We hope to give some advice to change the quality of employment and make contribution for the newly-built local university to provide better graduates serving for the local economic and social development. 


\section{A. Continuous Improvement of the Professional Career} Guide System

Firstly improving the course quality of employment guidance is the most urgent.One way is to adjust education resources, improve teaching methods and put emphasis on cultivation of students' employment ability and innovation ability. Secondly the teaching staff should have much more professional and practical financial and economic experience and professional course teachers and human resources managements are required and invited to carry out series of guidance course: career planning guide, professional quality training and employ guide. Thirdly university employment service agency should constantly improve the quality and increase the efficiency of its services. The employment service agency shall play the role of bridge between university and the employer, take employment as guidance, develop subscription type training and certificate type training.

\section{B. Innovating Talents Training Plans}

Harbin Finance University has six years of applicationoriented undergraduate. The course, universities localization and the personnel training goal are different with the traditional research or the teaching university. The school attach great importance to the establishment and adjustment of the plan of talents training and enhance the practice arrangement in education plan. Talents training plans must consider the demands of the graduate and enterprise, the change of society fostering applicative talents. Serving local economic construction is the essential concepts held among local colleges. School should do more efficient things to change the situation, such as increasing the hours of practice and strengthening the practical training base building and improving specialized teachers' practical ability. Many computer laboratories with software in campus only are used in class. By opening laboratories under the guidance of instructors the college students can use the sofeware resources in the laboratory and improve their creativity and practical capability. Talents training plans should also consider the demand of the students who want to pass the postgraduate entrance examination.

\section{Creating Good School Tradition and Academic Atmosphere}

First school encourage students to study with more diligence and create suitableconditions. The open hours of the university's library and classrooms will be prolonged to meet the needs of students as far as possible even in holidays. Second school and student clubs try to build bridges of communication between itself and other famous universities. Third school create open atmosphere and the teachers encourage students to create and discover. By strengthening college students innovate ability, they will have the sustainable development capacity in competition.

\section{REFERENCES}

[1] Liu Shu-yuan, Evaluation System on the Granduates Employment Quality based on Job Happiness Index, China University Students Career Guide, 348 (2016) 34-39.

[2] Staines,G.L.and Quinn,R.P.American workers evaluate the quality of their jobs.Monthly Labor Review, 1971 (1): 3.

[3] Brendan Burchell, Kirsten Sehnbruch, Agnieszka Piasna and Nurjk Agloni,The quality of employment and decent work:definitions, methodologies, and on going debates, Cambridge Journal of Ecnomics 2014 (38); 459-477.

[4] BRISBOIS R. How Canda Stacks up:the Quality of Work:an International Perspective [R].Ottawa: Canandian Policy Research Network Inc., 2003 (2): 31.

[5] Zhang Rui, Zhang Wei and Wu Cheng-Wei,China University Students Career Guide, 2006 (11) 59-64.

[6] Xuejie Bai ,Empirical Research Based on Undergraduate Employment Quality of University of Finance and Economics, 2016 International Conference on Economics, Management, Law and Education. 313-315 